\title{
O rascunho é a obra: o caso dos cadernos
}

Ana Kiffer ${ }^{1}$

Le soir, la nuit, il arrive

que l'on parle sans prudence.

M. Duras

Começo a escrever este texto de manhã bem cedo. Arrisco-me menos por aqui - digo: quando trato de escrever esse tipo de texto e não os outros. Por isso escolho a manhã, com o canto agudo dos pássaros. Nessa hora meus cadernos já estão dormindo. Já me encontro de retorno a essa dupla ou tripla jornada. Essa que os dias impõem às mulheres, mães, professoras, pesquisadoras, sonhadoras, escritoras, sem nome ou família, sem padrinhos ou mães. Um número grande de lutos hoje se somam às nossas lutas, às lutas das mulheres. Já não conseguimos escrever sem tudo isso. E mesmo quando é dia e a luz tenta invadir e clarear essas manchas imprudentes guardadas nos cadernos velhos, nos armários esquecidos, de um ou de outro modo isso acaba por se inscrever.

Em torno e em meio a todas essas mudanças por que passam a dicção, a condição discursiva, o desejo, o direito e as reivindicações das mulheres hoje, é que venho insistindo que a reflexão crítica merece vez por outra mostrar suas mãos. Mostrar que nem tudo passa incólume pelo corpo quando nos dedicamos ao ato do pensamento. Mas ainda assim parece que alguns mundos resistem mais do que outros a essa espécie de esboroamento do seu próprio sistema. Afinal ninguém garante que os efeitos desse trânsito entre os diferentes domínios das artes e da cultura, nem mesmo que essa guinada que coloca a subjetividade no centro dos acontecimentos econômicos e políticos venha a garantir-nos uma vida melhor ou mais feliz. (Como disse, já é de manhã. E a imprudência da noite. Bem, já foi interrompida pelas claras horas do dia.) Sob alguns aspectos não é apenas a posição ou o pensamento crítico em si mesmos que resistem a mostrar suas mãos - a máquina corpórea que os engendra e

\footnotetext{
${ }^{1}$ Doutora em letras e professora da Pontifícia Universidade Católica do Rio de Janeiro (PUC-Rio), Rio de Janeiro, RJ, Brasil. (Dorcid.org/0000-0003-3382-9926. E-mail: anakiffer@ gmail.com
} 
legitima e os braços que sustentam essas suas cadeias de produção. Há algo ligado ao próprio encadeamento exigido pelo pensamento ocidental - uma letra após a outra. Uma sintaxe clara. Pontuada corretamente. A condição universal que os postulados do pensamento devem ter. Exatamente o que hoje estamos indicando como sendo um discurso falacioso: o universal sempre foi descaradamente $o$ masculino, o branco, o dominante, o ocidental. Mas mesmo a exigência que alia o universal à necessidade de ter que contar-lhes algo e ainda fazer-me entender claramente é em si um efeito desse mesmo sistema opressor. Em parte, nele, a crítica reside em sua forca de convencimento. Segundo códigos precisos de erudição, de autores obviamente homens, que vem formando o arcabouço do nosso pensamento. Estou ainda aí. Esse tecido não se rompe numa noite.

Sou capaz de convencê-los porque falo e explico claramente, porque cito os autores necessários, porque lhes ofereço sentido. Ou melhor: reafirmo, sublinho e endosso um conjunto de sentidos já existentes. Pequenas são as alterações na ordem dos sentidos que um discurso crítico almeja ou consegue. Ainda mais se esse discurso se descobre, se desvenda e se faz a partir de uma posição feminina. Da palavra de uma mulher.

Contudo houve - a história mostra mesmo quando esconde, ou inclusive porque esconde - e há cada vez mais mulheres "imprudentes". Mesmo que a cautela seja sempre necessária. Nenhuma mudança pode ser brusca quando se trata de pensar outramente. É preciso que a tradição se mantenha de pé. Que não se quebre nada. A louça do pensamento é fina. Para efetuá-la é preciso que a louça passe através de vocês, mas sem cortá-los. E logo vocês, cujos corpos desconheço: oferecem-me ainda assim algo deles? Para que isso seja. Para que disso aqui algo possa ser, afinal.

A literatura, vocês sabem, a literatura em suas pautas, nos quadriculados dos cadernos do aprendizado da escrita, a literatura em suas jaulas, mas também em seus triunfantes impasses. Sobre eles, digamos: como dizer? Como dizer dos impasses por que passa um campo discursivo? Se pudesse acenar, desenhar, dançar. Mas como, utilizando-se da mesma ferramenta corrompida, ainda assim, tentar furar o muro que nos encerra. Esse com o qual hoje nos debatemos. E, depois, mesmo que diga, como colocar no mundo? Afinal, publicar, sabe? Como ingressar? Tutoriais? Mas e a criação? 
Não, espere. É preciso reordenar isso. Assim não vende, nem presta. Você balbucia, não escreve. Faça isso ser legível, digerível. Não se trata exatamente de todo um corpo que se ofereça para efetuar o sentido do texto. Basta um intestino.

\section{Nenhuma origem é possível}

Em 1998 cheguei a Paris para pesquisar os escritos de Antonin Artaud. E pelas mãos firmes de E. Grossman (minha orientadora na época) fui sendo introduzida na leitura de seus textos finais. Considerados - e muitos ainda hoje - ilegíveis. Eu os lia de uma posição estrangeira. Dessa posição, em parte, não entender nada pode ser regra da experiência inicial de contato. Logo, coloca-se a questão de como conviver com esse lodo do não entendimento. A insistência é um dos caminhos. A tradução, outro caminho. Colocava-me permanentemente se a incompreensão era um problema da língua? O esforço tradutório decerto adensava minha intimidade, meu processo de aproximação daquele universo. Mas ler os últimos textos e cadernos de Artaud em português não me aportava transparência, entendimento, clareza. Continuava em grande parte sem entender. Fui assim ultrapassando camadas, descobrindo-as, desdobrando-as. Acabei por entender, depois de tudo, que incompreensão demorada cria uma lama fértil. E que através dela é possível deflagrar muitos dos compromissos efetuados, consolidados e enrijecidos que fazemos para manter o solo do entendimento ficar estável. Descobrimos através do lodo o estrato duro da compreensão. É como descobrir o significado de uma palavra que não seja dado através de seu sinônimo. Ou seja: de outra palavra. Descobrir o significado de uma palavra através de uma experiência que sustente por algum tempo um "sem palavra". Ou talvez acessar apenas um dicionário de antônimos para desbravar a potência de seu contrário (disse Silviano Santiago numa palestra recente que fez na PUC-Rio sobre o seu livro Machado). Imaginem se estendemos essa reflexão da palavra para todo o texto. E do texto para um aglomerado de textos e cadernos. Que constelam os 18 dos 28 volumes das obras completas de Artaud. ${ }^{2}$ Imaginem que diante

\footnotetext{
${ }^{2}$ Em 1998, a obra de Artaud estava disponível na Collection Blanche - Gallimard em 28 volumes, com edição de Paule Thévenin. Tal edição sofreu nova revisão efetuada por Evelyne
} 
dessa extensão e complexidade a intensidade da incompreensão é capaz de revelar dispositivos bastante sofisticados que capacitam, mas também que congelam nossos processos de significação, de sentido, de entendimento, entre outros. Sob esse aspecto, o convívio demorado e a insistência de leitura de uma obra ilegível acabam por possibilitar um deslocamento, ou mesmo um corte epistemológico, naquilo que anteriormente consolidava nosso modo de pensar, logo de entender, de conceber o próprio sentido e sua máquina de produção de significação. Isso, claro, se continuamos a concordar que pensar depende, sobretudo, da capacidade do entendimento.

Em minha experiência de leitura dos cadernos do Artaud, ficou evidente como o deflagrar dos dispositivos congelados pelos processos de entendimento equivale, muitas vezes, ao ter que se alocar ou que alocá-lo no mundo do non sense, da loucura ou do equívoco. Toda essa massa textual, essa experiência e mesmo essa tentativa de contra efetuar o sentido, ou de fazê-lo funcionar de outro modo e em outra direção faz com que a recepção de sua máquina escriturária seja escoada, diria mesmo evacuada na esteira que o "sem sentido" ganhou no arcabouço do entendimento ocidental. Qual seja: ou procedimento estético do non sense (o que com Artaud não adere, posto que sua vida e corpo são postos no jogo da escrita), ou experiência da loucura. ${ }^{3}$ No caso desse escritor, muitas das leituras, inclusive das boas leituras, configuraram essas relações de incompreensão ou de suspensão do sentido como atributos do seu processo de loucura. Afinal o que fala um louco não faz sentido, correto?

Descongelar essa camada que alia compreensão com racionalidade ou razoabilidade e incompreensão com irracionalidade e loucura talvez seja ainda hoje uma das tarefas mais duras e difíceis do pensamento crítico. Por sorte não será ela que vamos enfrentar neste texto. Ao menos não frontalmente. No entanto saibam que para lidar com cadernos e, sobretudo, para partir de uma noção de caderno

Grossman em 2004, na Collection Quarto da Gallimard, com inserção de textos até então inéditos.

\footnotetext{
${ }^{3}$ Não por acaso, essa foi a primeira, longa e densa recepção de Artaud na França, que chegou inclusive ao texto de Gilles Deleuze, no que os especialistas consideram a primeira fase de sua filosofia, no caso, na obra A lógica do sentido (1998), e mais especificamente no texto de 1969 dedicado a Artaud e intitulado "Do esquizofrênico e da menina" (Deleuze, 1998, p. 85-96).
} 
deflagrada a partir desse escritor, de fato algo desse emaranhado nos acompanhará. Querendo ou não.

\section{Ainda Artaud}

Os cadernos de Antonin Artaud começaram a ser escritos em Rodez, em 1943. Artaud havia sido preso em Dublin em 1937, acusado de distúrbio da ordem pública. Foi deportado para a França e ficou dois anos desaparecido. Com ajuda de amigos e familiares, foi localizado em 1939, num asilo psiquiátrico em zona ocupada. Encontrava-se visivelmente abatido, enfraquecido, depauperado física, psíquica, política e afetivamente. Demorou mais quatro anos para que conseguissem transferi-lo para um hospital em Zona Livre. Foi quando, em 1943, chegou a Rodez, hospital dirigido por Gaston Ferdière, médico que Artaud já havia conhecido nos anos 1920 em Paris. Conhecido por ter um posicionamento mais "aberto e liberal", tratou-o com uma série bastante grande de eletrochoques. Ofereceulhe também pequenos cadernos escolares, desses quadriculados em que se aprende caligrafia. Em cinco anos, Artaud escreveu 503 cadernos. Sua obra literalmente explodiu. Sua intensidade escriturária foi posta em volume e também em incompreensão, variedade, entre outros. Ainda hoje desafiando a crítica e os editores.

Pode-se tentar desenhar algumas linhas que caracterizariam parte dessa experiência heterogênea que perfaz seus cadernos. (Mas não acredite tanto. Tudo isso é apenas uma tentativa do procedimento de compreensão de suas ferramentas, que domam aglutinando, reunindo as semelhanças em meio a tantas diferenças e disparidades.) Dessas linhas ressalto: $i$ ) desenho e texto mesclam-se e co-habitam o espaço da página sem hierarquias prévias entre um e outro, colocando tanto um quanto outro num regime de suspensão e de permanente instabilidade; ii) uma rítmica invade toda a escrita, inclusivo os traços que não formam letras ou as letras que não formam palavras, e essa explosão sonora acaba por encetar novos contornos para uma poéticacrítica que já não disserte sobre algo, mas o efetue, implicando o corpo

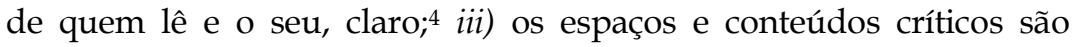

\footnotetext{
${ }^{4}$ Posteriormente muitos relatos vieram dizer que Artaud escrevia em pé, falando em voz alta, muitas vezes batucando ou batendo com uma pequena faca um pedaço de um tronco de
} 
gerados a partir dessa experiência de um corpo a corpo com as palavras-sons e os sentidos. Logo, todo o pensamento crítico ganha ritmo e poeticidade - e até certo ponto uma fabulação que por vezes o torna insustentável:

Eu soube ontem de uma das práticas oficiais, a mais sensacional das escolas públicas americanas e que fazem sem dúvida que esse país se creia na ponta do sucesso. Parece que, entre os exames ou provas pelas quais deve passar uma criança que entra pela primeira vez na escola pública, teria lugar a prova dita do licor seminal ou do esperma, e que consistiria em pedir à criança recém-ingressa um pouco de seu esperma a fim de inseri-lo num tubo e de guardá-lo assim pronto para todas as tentativas de fecundação artificial que poderiam em seguida acontecer. Isso porque mais e mais os americanos acham que lhes faltam braços e crianças, isso quer dizer que não lhes faltam trabalhadores, mas sim soldados (Artaud, 2004, p. 1.639, tradução nossa).

Mas, ainda assim, vamos insistir. A fabulação é um modo de construção desconstrutora do pensamento. Já sabemos disso. Muitos fizeram isso e nos legaram essa tarefa de fabular junto ou de desconstruir essa operação buscando deflagrar seus compromissos e mesmo o mundo que lhe encerra.

Notem, então, que no caso acima citado, sua fabulação procede de uma crítica que incide, ao fim e ao cabo, sobre a forma homem. Sobre o que a gera ou como essa forma é gerada: a família. Ou como é gerido: o Estado, a Igreja, a medicina (a anatomia). Enfim, a forma corpo/humano. Artaud decidiu perseguir a lógica da imagem e da semelhança em suas raízes e ramificações. E fez desse outro a quem devemos seguir para mantermos nossa forma estável algo que, mesmo que continue até certo ponto invisível, vigilante e imponderável, aparece em sua faceta destruidora, controladora, diria mesmo deformadora. Como se fosse preciso produzir "monstruosidades" para sustentar de modo apaziguado e estável a forma "pura" do homem branco e ocidental, imagem e semelhança de deus, máquina anatômica guerreira e competente, organizado, familiar, amoroso. Pois, justo ali, no final da Segunda Grande Guerra, vem

madeira que ficava em seu quarto, já nos últimos anos, quando estava no asilo de Ivry-surSeine, nos arredores de Paris. 
Artaud acusar os Estados Unidos de substituir, ou de recriar, através do poder médico e tecnológico, Deus, e com ele seu exército. Que decerto encarnava-se nos padres que não aceitavam sua religiosidade, nos médicos que não aceitavam e corrigiam suas ideias, nos amigos artistas que o isolaram durante tantos anos, em nome de uma radicalidade ameaçadora. Mas também vazava, e muito, toda sua história pessoal.

Artaud estava ali jogado em meio ao maior julgamento da história, em meio aos fornos crematórios, aos asilos que matavam uma imensa população de fome. E exterminando em silêncio numa França de alianças duvidosas ou certeiras com Hitler. Nada ali cheirava bem e sua escatologia é parte dessa vizinhança. Obviamente, sentia-se invadido - e estava. Colocando em marcha uma construção de corpúsculos linguageiros e pictóricos, capaz de suster a ameaça inimiga. Esse corpo desintegrando-se entre a doença - um câncer no reto, um ânus infestado - e a merda geral. Julgar sua palavra como sendo exclusivamente fruto de sua experiência pessoal equivale a dizer que todo fenômeno de incompreensão, ilegibilidade ou nonsense ou é puramente estético ou é loucura de um indivíduo.

Mas óbvio que sua palavra foi censurada, impedida; seu texto fabulatório e hiper-realista, enterrado; sua emissão radiofônica, interditada. Para acabar com o julgamento de Deus só veio à tona muitos anos depois, e até hoje nos desafia.

\section{Os cadernos, a obra...}

Os cadernos de Artaud são constantemente povoados por tudo isso que participava de sua ruína e derrocada literária, física, linguística: listas de comidas, cartas endereçadas, desenhos maiores, rabiscos, escansões rítmicas. Como se ele retomasse sua visão e explanação posta num de seus textos dos anos 1930 intitulado "O atletismo afetivo" (1984, p. 162-171). Mas nos cadernos ele já não fala sobre algo - o corpo afetivo e como cada órgão deveria ser sentido sensorialmente pelo ator de teatro. Ele já não o descreve, nem o indica. Ele brama, ao contrário, por um corpo sem órgãos. Em vez de falar sobre o corpo, algo vem ali se realizar e se inscrever, macerando a página, a letra, a língua. A linguagem partida ou sacrificada em sua máquina de sentido é chamada a agir, performando, avant la lettre. Também já não havia mais tempo, estava a morrer. Não havia mais espaço, os campos haviam sido 
abertos. A atrocidade estava à vista, à luz do dia. Seu corpo era um dos corpos supliciados, e sobre ele colocaram-se muitos. E a ele mesmo restava apenas materializar essa batalha.

Escrever tornou-se em parte esse combate laborioso entre ferramentas de tortura, suplício, corte, mas também de escansão rítmica, sopro, ar. Matérias pouco notadas quando se trata de texto pareciam ali assumir volume e densidade. A precariedade do material, do contexto e da vida impõe rever também a estabilidade e o conforto de nossas separações estáveis. Um caderno tornando-se o único espaço de realização possível faz com que tudo o que esteja à mão insurja em sua densa, e por vezes pouco notada, materialidade.

Como me disse Anne Sauvagnargues em conversa ${ }^{5}$ sobre seus cadernos, "toda criação insurge do constrangimento". Desenhar e escrever co-habitam os cadernos não porque decidem afrontar os gêneros, mas de fato porque esses cadernos dos quais falamos - $\mathrm{e}$ que não se definem como cadernos de desenho, tampouco como cadernos de escrita - habitam esse limbo da criação e estão como que pregados à precariedade que os rege. Para Anne Sauvagnargues, o constrangimento insurge, entre outros, através do número de cores limitadas pelas canetas que consegue ter nas mãos enquanto desenha em deslocamento ou locomoção. Essa precariedade material, que não se estabelece somente na sobredeterminação de estados-limite, como o de Artaud no asilo psiquiátrico durante a Segunda Grande Guerra, é uma espécie de intercessor primordial da feitura de cadernos; aquilo que os guia mesmo no escuro. E talvez seja essa a experiêncialimite que coloca a escrita de cadernos: a da precarização dos meios e suportes como força motriz para interrogar frontalmente as relações entre os objetos e as suas funções. Do mesmo modo que a experiência de leitura do ilegível promove um questionar profundo acerca das estabilizações de sentido e dos pactos da compreensão. É assim que esse profundo processo de instabilização das certezas por que passa o escritor é devolvido a seus leitores. E algumas questões que por vezes parecem voltar como que em espiral ao estado da

\footnotetext{
${ }^{5}$ A filósofa e prof ${ }^{\text {a }}$ do Departamento de Filosofia de Nanterre foi formada primeiramente nos estudos das artes, na Ecole de Beaux-Arts de Paris. Hoje é uma artista nas horas "vagas", e sua "arte" desenvolve-se exclusivamente em cadernos. Nesse trecho refiro-me a uma longa conversa que tive com Anne, em sua casa em Paris, onde pude acessar a maior parte de seus cadernos.
} 
consciência infantil através dos cadernos - interrogam seus feitores/leitores: quem disse que a língua escreve? E se sim, por que com ela não desenho uma letra bem grande capaz de roçar minha gengiva e fazer-me sentir que uma palavra é mais do que aquilo que até ali vi ou ouvi? Se perco meu paladar, quem me garante que não posso sentir o cheiro de uma palavra e alimentar minha barriga vazia? Poesia se mastiga? Com dentes capazes de sorver um novo corpo? Um corpo verbal-literal? E como ouso não perceber que o som de uma letra irrompe como que roendo a tessitura do texto e dos meus ouvidos, desfazendo os contornos estáveis do sentido que com ela foge? Num aglomerado de vogais capazes de balançar meu corpo e quiçá despertá-lo novamente: "kré puc te kré puk te pek li le kre pek ti le e kruk pte" (Artaud, 2004, p. 1.639).

\section{Só cadernos}

Depois disso tudo, parece óbvio dizer que a escrita de cadernos explora potencialidades que extrapolam sua própria realização na forma livro, exigindo uma relação material com o meio em que se escreve e com as ferramentas disponíveis. No caso de Artaud, ele começa experimentando a página e abandonando a exclusividade da escrita da esquerda para a direita. Desse modo, acaba por entrelaçar o traço do desenho ao traço da escrita, assim como explora uma verdadeira cena sobre o papel que faz com que a página abandone sua feição plana e a leitura, sua vocação linear. Também, repito, toda a dicção de Artaud é contaminada por uma força poética sonora, que explora as potencialidades das palavras proferindo-as em voz alta, escandindo-as na cena mesma da escrita, por meio de incisões, golpes de lápis, pancadas, figuras pontiagudas que criam, ao mesmo tempo, além de uma "batucada" sonora, um acontecimento visual e auditivo.

Tudo isso obviamente acarreta um uso das margens das páginas de seus cadernos numa potência nunca antes imaginada: muitas vezes os textos "marginais" contradizem tudo o que foi escrito no texto central, incorporando à obra seu caráter paradoxal de modo irrevogável. O uso das margens também faz com que a leitura de seus cadernos seja uma atividade "física", já que estes devem ser revirados, arrancandoos da possibilidade inerte que o "livro" (e o corpo habituado a esse modo de visão?) mais ou menos possui. Por isso mesmo foi impossível 
editá-los nesse formato. Esses cadernos sobrevivem nessa espécie de espaço em suspensão, posto que tampouco alçam o voo ou o desejo de serem "mais" do que cadernos para existirem nas vitrines de museus como "livro de artista". Afinal eram apenas cadernos de caligrafia escritos por um escritor interno em um asilo psiquiátrico.

\section{Sublinhando a rasura histórica}

Eu diria - depois de dois anos de pesquisa sobre cadernos e vinte anos de pesquisa sobre a obra de Artaud e alguns textos, artigos, palestras e cursos proferidos em diferentes ambientes acadêmicos e/ou artísticos - que a quase nenhuma bibliografia acerca dos cadernos $^{6}$ (salvo quando se edita ou expõe cadernos de escritores e artistas) aponta para algumas questões ainda hoje relevantes ao campo das relações entre literatura e cultura e literatura e outras artes.

Primeiramente, deve-se notar que a própria obviedade do caderno, o fato de todo mundo ter um caderno (e não apenas escritores e artistas) fez com que esse objeto não alcançasse o valor ou a qualificação necessária para que fosse pensado em sua singularidade. Afinal como aliar singularidade à banalidade ou ao uso comum? $\mathrm{O}$ pensamento ocidental ainda atrela a noção de singularidade à noção de excepcionalidade. Somos bem mais modernos do que de fato nos cremos. Depois pode-se dizer que essa banalidade encerrou toda a recepção do caderno, quando houve, como mero suporte, impedindo uma reflexão que justificasse diferenciá-lo, por exemplo, do diário. No entanto, qualquer um sabe que um caderno não necessariamente é um diário, e vice-versa. É preciso notar que a estabilidade da noção de diário (mesmo que tenha havido um profundo alargamento em torno das pesquisas acerca das escritas de si), ainda que abrace hoje um conjunto fértil de relações materiais com o traço, o desenho, a escrita e

\footnotetext{
${ }^{6}$ Estou me referindo aos cadernos que existam fora do âmbito dos manuscritos (como aqueles que deram origem às obras), assim como em diferença com o que vimos tratando e lendo como forma diarística, no caso da literatura e em diferença, no caso das artes visuais, daquilo que foi recebido como livro de artista. Logo, entendam que se trata aqui de duas pontuações: estou recortando e pensando os cadernos exclusivamente no regime da literatura e das artes a partir do século XX. Segundo, não estou defendendo uma essência do caderno ou uma ontologia do que seja o caderno, mas, sim, traços de uma singularidade que o desloque da recepção da forma diário ou do livro de artista. Estou simplesmente buscando "caracterizar" um objeto, para falar no jargão das pesquisas em construção.
} 
a plástica, remonta à estabilidade - no espaço literário - da relação entre narração e interioridade. Estabilidade essa que remonta aos efeitos da cristianização, aos procedimentos de confissão e, em seguida, ao atos fundacionais do sujeito moderno (Foucault, 2018). O efeito disso se deixa notar por meio, entre outras, dessa dependência entre a noção de sujeito e a noção de enunciação (mesmo que seja para inferir suas não coincidências, o paradigma se mantém), fazendo com que uma reflexão mais atrelada aos processos de dessubjetivação nomádica, ou mesmo aos processos pulsionais (instintivos) e assubjetivos $^{7}$ da escrita e de seus modos de montagem de uma outra máquina escriturária continuem menos observados, ou mesmo menos passíveis de serem valorizados e/ou vistos no interior do gênero diário. Ou seja: tudo aquilo que o caderno - até mesmo por ser o primo pobre do diário - vem usufruindo sem precisar pedir licença.

A máscara que cai com o caderno não é essa do segredo (sujo ou não), da revelação que os diários e as cartas temem ao mesmo tempo que mostram, logo desejam, como boas senhoras histéricas. A máscara que cai com os cadernos é justamente aquela que mostra o desmonte da relação entre singularidade e excepcionalidade, aquela que vai reivindicar para si a precariedade dos processos subjetivos que envolvem a criação, logo, a precariedade (bastante distante de toda genialidade) que percorre todos os processos de criação, seus constrangimentos no sentido mais físico e violento do termo, a desmitificação da figura do escritor e do artista. Uma das consequências dessa desmistificação ${ }^{8}$ seria a abertura de processos capazes de interrogar acerca dos critérios que definem quem pode ser, num determinado contexto, numa época e numa certa geopolítica, considerado escritor ou artista - e, obviamente, quem não pode ser. Isso perpassa um conjunto de valores sociais, raciais, de classe que, ao fim e ao cabo a tão desejada estabilidade da língua só vem concentrar. Escrever bem ou escrever mal segundo padrões

\footnotetext{
${ }^{7}$ Sobre essa questão, apresentei um texto no último congresso da Associação Brasileira de Literatura Comparada (ABRALIC), realizado na Universidade do Estado do Rio de Janeiro (UERJ) em 2017. Disponível em meu blog Mar da Carne: <https://anakiffer.blogspot.com/2017/08/fulminato-7.html〉.

${ }^{8}$ Sabemos como muitos escritores em suas entrevistas falaram da necessidade de desmistificar a criação, a literatura e inclusive a própria figura do autor. Aqui estamos apenas querendo expandir essa seta e essa reflexão para o campo mais sistêmico do literário, assim como dos cortes que ele opera nas sociedades.
} 
de aproximação ou de fuga da língua, do corpus e socius é sempre algo que transtorna a estabilidade de um tempo e de um lugar.

Seria preciso dizer, ainda sob esse aspecto, que a banalidade do caderno inscreve-se no fato de que essa ferramenta foi absolutamente fundamental para inventar e manter acopladas - nas sociedades ocidentais modernas - a ideia de escrita à experiência de um corpo docilizado. Os cadernos remontam ao aprendizado da escrita, justamente ao "escrever bem". Ao grande e primeiro corte que se opera entre quem pode vir a ser escritor e artista - ou seja aquele que foi "contemplado" (não mais pela figura de deus, mas pelas letras do alfabeto) e aquele que dificilmente virá a ser escritor. Se estivéssemos na Suécia ou numa ilha na qual todos foram abençoados pela mesma oportunidade - i) docilização dos corpos; ii) processo de ingresso na cultura simbólica ocidental; iii) domínio da língua e da escrita -, decerto os cadernos revelariam a necessidade de outras interrogações. Mas num país como o Brasil, não notar a aliança entre a rejeição aos cadernos (por serem muitas vezes escritos nessa língua apátrida, dejetos resistentes ao curto e falho processo de alfabetização, e pela constatação que eles abrem - feita de uma imensa obviedade - ao dar a ver a oportunidade que seria se os processos e as ferramentas de criação se democratizassem $)^{9}$ e a fundação de um espaço literário e artístico (cultural) até hoje extremamente elitista e branco parece ser, no mínimo, malintencionado.

Todos esses elementos deveriam fazer notar que não é por acaso que, quando os cadernos insurgem, na modernidade artística, política e literária em sua singularidade, quando mantêm seu nome de batismo, digamos assim, sem precisar travestirem-se ou elevaremse à condição de diários ou livros de artistas (muitos deles não mais que simples cadernos), eles se ligam a algum regime de exceção: Cadernos do Cárcere (Gramsci), Cadernos Asilares (Artaud),

\footnotetext{
9 Notem o caso de Maria Carolina de Jesus e a "edição" (reescrita, supressão, corte entre outros) de seus cadernos em diários e a sua curta e até hoje polêmica inserção no espaço literário. Mas notem também as reivindicações mais recentes da cultura negra e a nossa dificuldade para ouvi-las. Notem como os cadernos foram até hoje a única ferramenta - escrita - de transmissão em muitos espaços do pensamento de matriz afrocentrada, como nos terreiros de candomblé. E que obviamente esses cadernos, feitos de línguas instáveis, processos de cura, segredos religiosos, testemunhos da cruel escravização desse povo, desenhos, rezas e magias, entre outros, permanecem ignorados, desvalorizados, reprimidos, quando não sucateados.
} 
Cadernos de África (Barcelò). Isso acaba por mostrar mais a nossa dificuldade em vê-los do que a deles de se in(e)screverem. Esse controle de sua aparição alerta para dois caminhos igualmente significativos. Um deles, mais palatável, indica que o caderno, quando permanece como ferramenta de escrita após os anos de escolarização e domesticação das vidas, continuará apontando ou indicando algum tipo de desarranjo ou de falha desse próprio processo (de docilização, de ingresso no sistema da cultura, falha por conseguinte de inscrição do e no próprio sistema simbólico). $\mathrm{O}$ outro caminho, um tanto mais árduo, indica que a aparição desses cadernos (dejetos) indicaria a necessidade de questionarmos os contornos que definem hoje o que é ser escritor ou artista, ou quem detém esse corpus discursivo que delineia contornos estéticopolíticos numa determinada época e lugar, e quem ascende ou não a essa posição - por conseguinte, um desarranjo no status quo dos espaços literários, artísticos e culturais.

Vejam que, sob esse prisma, nenhuma reflexão ou conceito que busque apenas considerar exclusivamente a experiência estética seus procedimentos, contornos subjetivos ou novas interioridades, ou a expulsão desse próprio interior hoje desenhado como um si mesmo heterogêneo e exterior, o esvaziamento dessa ou daquela particularidade estética (o texto, a cor, o corpo) como diagnóstico do cenário artístico instituído ou de um gênero artístico - pode ser feito sem sujar as mãos em seus vínculos reflexivos com o exercício do poder que erigir tal conceito engendra hoje. No contexto das lutas incontornáveis que (re)surgem hoje, afirmar apenas a heterogenia dos regimes artísticos ou a expansão estética dos gêneros ou a instabilização destes, desconsiderando solenemente que esse estado da arte assenta-se sobre cortes geopolíticos muito drásticos, em alguns casos verdadeiros estados de dominação, é no mínimo ingênuo para uma crítica que se quer tão sofisticada.

Sob esse aspecto, esse modo de formulação conceitual evita justamente tocar no solo que os cadernos, entre nós, revolvem: a precariedade linguística de um caderno não pode ser vista, no caso deste país, apenas como desejo de performatização ou de vazio subjetivo da e na contemporaneidade. Dito de outro modo: parece difícil, se queremos tocar no fluxo das mudanças exigidas em nossas sociedades hoje, aliar-se a um pensamento literário ou 
estético que negligencie esse grande silenciamento e impedimento de camadas que foram alijadas no seio de nossas reflexões, independentemente do conteúdo delas. Camadas que hoje insurgem sobretudo através das reivindicações das mulheres, dos negros e negras e do povo ameríndio do Brasil, exigindo-nos um verdadeiro descentramento, eu diria mesmo uma verdadeira subversão epistemológica como ainda não tínhamos visto na história desse país. Obviamente que essas reivindicações e exigências desvelam estruturas camufladas por séculos, duros e consolidados estratos de um imenso machismo e racismo entre nós. Camadas que existem ou que se deixam notar na banalidade, na precariedade e na subalternidade dos cadernos - e inclusive no fato de permanecer como gênero inexistente nos estudos modernos e contemporâneos da literatura. Não estou dizendo que nosso pensamento crítico deva voltar-se exclusivamente para esses campos. Tampouco que não haja pensamento crítico quando se exerce uma reflexão puramente estética que desconsidere os arranjos geopolíticos. Estou apenas indicando os compromissos que fazemos todos quando decidimos silenciar ou, no mínimo, não ver esses arranjos geopolíticos.

Tampouco estou colocando sobre os cadernos a descoberta da pólvora ou uma caixa de pandora, pensando-o como um "novíssimo" objeto a ser considerado por todos. Isso seria apenas continuar funcionando no mesmo padrão epistêmico, acreditando que um objeto novo, descoberto e domesticado pelo pesquisador é suficiente para mexer com as estruturas existentes. Interesso-me mais por essa aparição instabilizadora que o caderno pode provocar em nosso olhar ou em nosso modo de teorizar as novas escritas artísticas, subjetivas, intelectuais e críticas. Por isso, o que estou tentando dizer com os cadernos, ou o que ouço daquilo que muitos cadernos me disseram, ${ }^{10}$ assim como ouço do gesto de outros pesquisadores diante de outros campos e questões, é que a nossa

\footnotetext{
10 Claro que parto aqui dos cadernos do próprio Antonin Artaud e como até hoje eles desestabilizam o sistema de recepção e edição na França. Mas, no decorrer da pesquisa, entrei em contato com alguns cadernos de mães de santo, assim como alguns cadernos de intelectuais reconhecidos que tanto num quanto noutro caso, mantêm, por diferentes razões, esse conjunto significativo de sua experiência e modo de pensar e/ou criar apagado ou em segredo, indicando, até certo ponto, essa espécie de desautorização que o caderno porta.
} 
ordem do discurso deve ser necessariamente abalada se ouvirmos esses novos atores, essas novas dicções escritas "em silêncio" e nas bordas. Esse acoplamento entre camadas discursivas desconsideradas e escritas de borda na trajetória de diversos atores parece-me apontar para aquela temível materialidade do discurso, como pontos de inflexão e transtorno por que passa um certo momento histórico. De fato, os efeitos disso parecem atingir muito mais - assim ao menos desejo e diagnostico nessa empreitada crítica - nossos assentos epistêmicos.

De forma bastante resumida, a discussão sobre a escrita, a precariedade e o desconcerto que os cadernos operam num certo arranjo discursivo da arte e da literatura moderna e contemporânea parece encetar aqui que uma noção prática de caderno diz respeito àquilo que, por um lado, desmonta um conjunto de práticas teóricas que envolvem, forjam, sustentam, potencializam ou não os contornos do que o sistema simbólico ingere e aquilo que esse mesmo sistema expele. Isso se dá tanto no nível subjetivo - como um artista pode rever sua obra através dos cadernos - quanto obviamente político: transformar um caderno num diário, editá-lo, fazê-lo contar e censurar tudo o que é lapso, falha, ausência de sentido é fazer com que a literatura e o discurso funcionem numa determinada direção de sentido, logo, em direção a um determinado télos. O que ouvimos hoje, quando consideramos essas camadas discursivas e culturais silenciadas, é exatamente a necessidade de rever esse télos, a direção e o corte fundador de uma episteme que, mesmo instável, ainda governa nossos estados culturais e (necro)políticos.

\section{Todo caderno é uma práxis da escritura}

Essa noção prática de caderno foi sendo construída através de algumas ações que circundavam ou que bordejavam àquelas já previstas para o desenvolvimento de uma pesquisa acadêmica como o levantamento e a consulta de fontes bibliográficas, visitas a acervos, cadernos de artistas e/ou escritores etc. Essas ações outras envolveram um conjunto de transformações: i) da minha própria dicção crítica; ii) da prática - didática - na docência em pósgraduação; iii) da proposição de cursos crítico-curatoriais - ateliês para artistas em espaços não acadêmicos; iv) da contaminação 
crescente entre os regimes ficcionais e poéticos e os regimes críticos e políticos que passei a engendrar em todas essas atividades; $v$ ) da militância contra o racismo e da aproximação com o pensamento de matriz afrocentrada, suas práticas, valores, suas escritas precárias em cadernos eles mesmos à beira das práticas corpóreas, ritualísticas, políticas e estéticas na tentativa de sobrevivência de um modo de existência e vida em muito e há muito apagadas, quando não impedidas.

De todo modo, para além do contexto político-subjetivo em que se insere essa pesquisa, o mais importante a salientar seriam os desdobramentos que uma noção prática de caderno oferece para quem pensa os regimes escriturários no contemporâneo. Isso porque nota-se, para além dessa presença ininterrupta que faz oscilar ou que faz passar a letra dentro do desenho e vice-versa (grafismos, mapas, diagramas, linhas), uma grande instabilidade linguística ligada não mais ao traço pictórico e sim às línguas precárias e subalternas que existem como estratos esquecidos ou apagados de nossa história em muitos dos nossos cadernos. A possibilidade de uma escrita mais próxima à oralidade - presente e propiciada na singularidade do caderno, oralidade vista tanto em sua escrita de urgência quanto em sua insubmissão aos códigos, apontam para essas camadas ou estratos apagados de uma ou várias línguas "inexistentes" entre nós. Também a presença maçante da corporalidade - seja das funções do corpo ou de sua estranha e íntima relação com a palavra -, como se ali nos cadernos a palavra viesse socorrer ou efetuar a possibilidade de existência de corpos que negligenciamos ou impedimos de viver, indicam essa subalternidade dos corpos que habitam ou escrevem cadernos. Seus balbucios, tiques, repetições, taras, incongruências, sujeiras, imperfeições, entre outras, são matéria profícua e presente nos cadernos. Como se uma ars erótica (tomando o termo do Foucault da História da sexualidade) se manifestasse nesse ambiente um tanto degradado - malcuidado? - da escrita de cadernos. Nada disso aparece preso ou exclusivamente determinado por relatos sobre esses corpos - ao menos essa tem sido a tônica dos cadernos que até agora pesquisei. ${ }^{11} \mathrm{O}$ caderno parece borrar a temporalidade do

${ }^{11}$ Refiro-me de modo mais contundente aos Cadernos de Artaud, aos Cadernos de Miquel Barcelò, aos cadernos (inéditos) de Anne Sauvagnargues, alguns conjuntos de notas, cadernetas 
passado, inscrevendo-se num presente sem data, como se esses estratos ou camadas "apagadas" sobreviessem, existindo simultaneamente. Por isso, posso começar hoje um caderno e voltar a escrevê-lo dez anos depois. A marcação diarística, a linha cronológica, a sucessão dos dias que determina um modo de narratividade não participa ou pelo menos não determina a escrita e a singularidade desses escritos, sendo esse um dos traços mais marcantes que o separam da forma diário. Logo, essa inscrição dos corpos se perfaz na criação de uma atmosfera do imediato. Artaud, num de seus últimos escritos, indica esse desejo de imediato, de uma linguagem de eficácia sobre o corpo que buscou com seus cadernos: "quem sou eu? / de onde venho? / eu sou Antonin Artaud / e que o diga / como sei dizer/ imediatamente / vocês verão meu corpo atual / voar em pedaços / e se reunir / sob dez mil aspectos" (Artaud, 2004, p. 1.663, tradução e grifo nossos).

Observem a relação direta entre um modo de dizer e sua imediata relação com a transformação do corpo atual (do escritor e do leitor). Esse imediatamente - que povoa os cadernos de listas, de letras cheia de volumes, como que feitas corpos, de receitas mágicas, de ciframentos ou mensagens - deixa ver que o imediato quer de algum modo colocar a experiência da linguagem fora do paradigma que a inseriu como campo mediador. Imediato quer dizer também criar uma escrita sem mediação. Ou seja, destituí-la de sua própria função: entre os homens e Deus - a Bíblia; entre os homens e a justiça - o texto da lei. Uma linguagem não mediada, talvez aponte, entre outras, nos cadernos de Artaud dos anos de 1943 e 1945, para essa escrita performática, a ser posteriormente realizada pelos corpos dos artistas e suas múltiplas insurgências.

No entanto, mesmo a performance não resolve todos os impasses conceituais para pensar o não mediado. Mesmo que falemos dele e o admitamos como vértice da cultura contemporânea, como o fizeram Derrida (2010) ou Deleuze-Guattari (1980), por exemplo, algo sempre soa místico ou hermético quando nos aproximamos desse campo ou dessa tentativa de reflexão ou inscrição do não mediado. Tenho a sensação de que usamos um ou outro conceito - que insurge nos

e papéis de Louise Bourgeois, mas também a alguns cadernos da ialorixá Wanda d'Omolu e aos relatos que esta me fez dessa prática de cadernos dentro dos terreiros de candomblé. 
fazendo indicar esse processo de não mediação -, mas rapidamente o esvaziamos dessa potência. Como se a própria experiência do pensamento e da linguagem requisitasse expelir ou neutralizar esse corpo estranho, para manter o bom funcionamento do seu próprio corpo. Muito disso foi acontecendo com o uso indiscriminado da noção de performance no âmbito da escrita. Apesar de ter aparecido no contexto dos anos 1960 e 1970 (Fischer-Lichte, 2011) a noção retorna nos anos 2000 e rapidamente desgasta-se em sua potência de reivindicação e mesmo de comprometimento com essa alteração corpórea dos meios que atravessa, indo alojar-se no senso comum das aparências ou dos regimes discursivos da superficialidade. Decerto as teorias de gênero (Butler, 1990; Preciado, 2002) foram fundamentais para recolocar as relações entre performance e escrita. Assim como a noção de "presença" (Gumbrecht, 2010), mesmo que essa ainda insurja muito comprometida com o arcabouço metafísico, certamente não conseguindo engendrar nenhuma propulsão ou atuação que não seja a da reflexão sobre os corpos. Mas a linhagem que abre Artaud, e que ainda merece maior atenção, vem permitindo pensar a não mediação ou o imediato num para além da dicotomia proximidade versus distância, corpo versus espírito, alertando para os riscos de se tomar a noção de performance como a de uma produção de presença, ou mesmo o de uma imediata presença física como atributos do corpo e de sua exigência de proximidade - seja entre o corpo e o texto, o texto e a vida, autor e leitor/espectador/participador e mesmo entre crítico e obra. Isso não significa que ele, o imediato, não encete um questionamento acerca da distância. Mas trata-se muito mais do modo e da posição que a distância exerce, cria, recorta e instaura que de uma revêrie da proximidade total e fusional, que pressupõe, ela mesma, um corpo apreendido em seu diagrama físico e em demarcações que daí advêm. O profundo questionamento acerca da natureza dos corpos e da escrita é o que faz dos cadernos de Artaud um manancial de questões ainda não respondidas ou consideradas mais de perto, pelo arcabouço da cultura ocidental.

Um corpo reflexivo dentro desse escopo não considera sua potência material e propulsora. Esse pensador estritamente reflexivo sequer pretende colocar em jogo as (im)potências (entendidas aqui como limites, zonas demarcadoras, diagramas físicos, bordas) do seu 
"próprio" corpo. Por outro lado, somos empurrados para leituras que querem ver aí, no avesso das abstrações "limpas", uma espécie de literalidade suja ou louca, como se toda materialidade indicasse um furo no sistema simbólico e sua inevitável penetração desse real traumático e irrepresentável, logo, cheio de equivalências sem sentido, mas com peso e matéria remetidos ao impossível dessa simbolização - outro tipo de impotência dos corpos, de novo fadado ao indizível. Prefiro entender que ainda tateamos nessa esfera, e sobretudo notar que haverá sempre essa necessidade de dejeção por parte das estruturas do pensamento e da linguagem em conceber o não mediado. Dejeção que participa também da expulsão dos corpos "estranhos" que porventura possam colapsar sua própria organização.

\section{Dos corpos e/m cadernos}

Uma saída para pensar esse não mediado sob outro viés que não o da performance ou o da presença parece-me ser a atenção acurada aos procedimentos processuais. Isso porque, se no mundo das artes visuais, plásticas, teatrais, e mesmo no campo da dança e do cinema - observamos um crescimento constante das obras ensaios, ${ }^{12}$ dos ensaios abertos, das performances em processo, das instalações transitórias, feitas de matérias degradáveis, no mundo da literatura, essa questão fica mais complexa. Vamos dizer que a forma livro é o que o museu é para a obra de arte, mas com uma diferença: normalmente a obra de arte contemporânea questiona a formamuseu. No caso da literatura o questionamento da forma livro só produziu ou formas ainda mais supremáticas de livros artísticos, numerados, raros ou transitórios ou formas artesanais, que circulam num mercado "alternativo", que por fim endossa a contradição entre o dentro e o fora do sistema literário. O próprio circuito de construção do autor impõe esse destino único. Mesmo que outras vias (zines, feiras, performances poéticas, revistas on-line) se

\footnotetext{
12 Ensaio aqui não no sentido escriturário desse termo no domínio das ciências humanas, sociais e literárias, mas em seu sentido propriamente teatral de "repétition", termo que em francês alude a essa dupla injunção entre algo que opera num movimento circular ou espiralar (feito a cada vez de pequenas variações) e também de ensaio, enquanto ensaio e erro, rascunho, algo propriamente inacabado.
} 
disseminem, sabemos que o paradigma da edição, das editoras e dos livros é centralizador, estável e alvo de destinação, senão única, a mais importante para um escritor. Afinal, quem escreve quer ser lido. Essa estabilidade da forma livro remonta ainda à própria estrutura da língua, banhada pela linearidade, que exige uma submissão à temporalidade cronológica e a visão linear do homem e da história. Ou seja: tudo só pode se passar numa ordem sucessiva, numa visualidade retilínea. O que não coincide com os processos, em sua maioria gráficos, espiralares, diagramáticos, volumosos e quase nunca retos, sucessivos e muito menos evolutivos. Esse livro cume é também o "livro túmulo" (Artaud, 1984), fechado e em silêncio. Sua forma decerto dificulta a apreensão mais viva daquilo que ali dentro se encontra. E se comparamos às mutações da forma pictórica, veremos que a forma livro praticamente não mudou. Enquanto o quadro já praticamente não existe mais, ou quando existe, está sempre, de um modo ou outro, sendo interrogado em sua forma. É óbvio que essa inércia material assenta-se sobre aquela organização de que falava acima. E fica claro que toda desorganização nesse sistema pode ser penosa, desastrosa, caotizante, imponderável. Ela já está acontecendo, mas como que em brechas e submundos. Ainda não temos como analisar seus efeitos, sobretudo quando se está interessado, caso dessa pesquisa, em analisar os efeitos no nível político-subjetivo e não meramente tecnológico ou estatístico. O livro eletrônico é ainda um livro, ele não muda nada, ou quase nada, para a discussão que encetamos.

No entanto, é obvio que a literatura - mesmo que ainda se assente sobre a forma livro e o que a forma livro impõe - está neste mundo. Em contato com todos os elementos que nos circundam. Sejam as brechas - submundos, periferias, favelas, prisões, campos de refugiados, zonas de guerra etc. -, sejam as outras artes. Isso depende mais da localização geopolítica do escritor. E é a aproximação ou a intensidade dessas zonas de contato que adensam os processos pelos quais passa a literatura hoje. Se grosso modo pode-se dizer que desde os anos 1950 a literatura abriu-se às formas do inacabamento, às suspensões, aos lapsos e falhas narrativas, ou mesmo ao investimento antinarrativo, nota-se que os procedimentos processuais se inscreveram aliando-se à forma final da obra livro. E não apenas 
nas margens ou no que se considerava para-textual: cartas, diários, cadernos. Mas, assim como no domínio das outras artes houve um certo desmonte radical da obra em prol dos processos como se tivéssemos aberto a caixa de pandora e encontrado apenas as nossas próprias dúvidas e incertezas -, frutos de um mundo distópico, de um rebaixamento dos grandes quadros teórico-críticos que explicavam onde estávamos, assim como um rebaixamento dos contornos identitários, de gênero, políticos e subjetivos, na literatura houve um olhar que teve de se voltar para as preparações, os objetos cotidianos da escrita, quase que exigindo um corpo a corpo que redefinisse ou ao menos interrogasse seus novos contornos. É certamente nesse contexto que se insere a pesquisa com os cadernos.

Há algo um tanto brutal e ao mesmo tempo delicado quando nos aproximamos do modo como os procedimentos processuais singularizam-se na escrita de cadernos. Há algo que faz com que os processos assentem-se sobre uma certa instabilidade imprudente. Leiam tal imprudência como a que foi dita por Duras na epígrafe deste texto. Uma instabilidade crua. Uma certa carne viva. Não porque ali segredos sejam secretados, mas o modo de fazer. Exatamente o que a literatura nunca conseguiu mostrar. Afinal como se escreve? Essa é a questão do caderno: não o que se escreve, mas como, quais os meandros. Essa instabilidade crua ou imprudente não me parece ser, ou ao menos seria interessante não pensá-la exclusivamente como rascunho ou como testemunho em direção à obra. De fato, observa-se que os cadernos em seus processos oferecem um certo modo de funcionamento da escrita, que não mudará porque a forma livro foi atingida. Essa singularidade do instável é fenomenal quando se trata da escrita, porque ali vemos algo destemido. Ainda não estão os outros. Como disse Artaud acerca do público para o teatro que inventava: "O público: primeiro é preciso que este teatro seja" (Artaud, 1984, p. 126). Há uma certa brutalidade. Uma imprudência. Jacques Derrida dizia que escrevia seus cadernos inclusive quando dirigia (apud Bailly, 2016, p. XVII), arriscando a própria vida, em busca ou na existência dos rastros. Os cadernos são trilhas abandonadas e ao mesmo tempo os sulcos profundos e intensivos da escrita; uma angústia antes da forma fixar-se, uma atmosfera sem fotografia, um mapa de sensações. Os processos são 
feitos disso e isso é a obra. Como disse Deligny: "Quanto à maioria desses traços, faz tempo que esquecemos de quem são. Esse esquecimento nos permite ver 'outra coisa': o resto, refratário de toda compreensão" (Deligny, 2015, p. 160).

Os cadernos são nossos restos, restos do nosso mundo. Já a noção de rascunho diz respeito apenas aos inevitáveis dispositivos de controle, de domesticação e de abrandamento em função dos códigos que determinam uma época, um horizonte que lê assim. Aproxima-se um pouco a hora de trazermos para dentro do jogo e da disputa esses contradispositivos, que assumem a vulnerabilidade em se fazendo, que a tomam em seus passos e braços e não apenas sobre elas falam...

\section{Referências}

ARTAUD, Antonin (2004). Oeuvres. Édition d'Évelyne Grossman. Paris: Gallimard. (Collection Quarto)

ARTAUD, Antonin (1984). O teatro e seu duplo. Tradução de Teixeira Coelho. São Paulo: Max Limonad.

BAILLY, Jean-Christphe (2016). L'Ineffacé. Saint-Germain la Blanche-Herbe: IMEC.

BUTLER, Judith (1990). Gender trouble: feminism and the subversion of identity. New York: Routledge.

DELEUZE, Gilles (1998). A lógica do sentido. São Paulo: Perspectiva.

DELEUZE, Gilles; GUATTARI, Felix (1980). Milles Plateux capitalisme et schizophrénie 2. Paris: Minuit.

DELIGNY, Fernand (2015). O aracniano. São Paulo: n-1.

DERRIDA, Jacques (2010). Força de lei. São Paulo: Martins Fontes.

FISCHER-LICHTE, Erika (2011). Estética de lo performativo. Madrid: Abada.

FOUCAULT, Michel (2018). Histoire de la sexualité 4: les aveux de la chair. Édition de Frederic Gros. Paris: Gallimard.

GUMBRECHT, Hans Ulrich (2010). Produção de presença: o que o sentido não consegue transmitir. Rio de Janeiro: Contraponto. 
KIFFER, Ana (2012). Sobre limites e corpos extremos. In: SCHØLLHAMMER, Karl Erik; OLINTO, Heidrun Krieger (Org.). Literatura e criatividade. Rio de Janeiro: 7Letras. p. 22-31.

KIFFER, Ana (2017). Escrita de corpos efêmeros - Cadernos. In: GORRILLOT, Bénédicte et al. (Org.). Poesia e interfaces: operações, composições, plasticidades. Rio de Janeiro: 7Letras.

PRECIADO, Beatriz (2002/2011). Manifesto contrasexual. Barcelona: Anagrama.

Recebido em 29 de setembro de 2017.

Aprovado em 26 de maio de 2018.

\section{resumo/abstract/resumen}

\section{O rascunho é a obra: o caso dos cadernos}

Ana Kiffer

Este artigo subdivide-se em três momentos: $i$ ) breve histórico da pesquisa com cadernos; ii) o desenvolvimento e os desdobramentos de uma noção prática de cadernos para e na cultura contemporânea; e iii) na arte já se sabe há bastante tempo que os procedimentos processuais não são o rascunho da obra vindoura. Mas quais os efeitos disso para o campo da escrita e da literatura?

Palavras-chave: Antonin Artaud, cadernos, escrita.

\section{The draft is the oeuvre: the case of the notebooks}

Ana Kiffer

This article is subdivided in three sections: i) a brief background about the research on notebooks; ii) the development and consequences of a practical notion of notebooks for and in contemporary culture; and iii) in art it has been known for while that the processual procedures are not the draft of the future oeuvre - however, what are the effects of this for the areas of writing and literature?

Keywords: Antonin Artaud, notebooks, writing. 


\section{El borrador es la obra: el caso de los cuadernos}

\section{Ana Kiffer}

Este artículo se subdivide en tres momentos: i) breve repaso histórico de la investigación con cuadernos; ii) el desarrollo y las consecuencias de una noción práctica de cuadernos para y en la cultura contemporánea; y iii) en el arte ya se sabe hace tiempo que los procedimientos procesuales no son el borrador de la obra venidera - ¿pero cuáles los efectos de eso para el campo de la escritura y la literatura?

Palabras clave: Antonin Artaud, cuadernos, escritura. 